\title{
The effect of salinity on the biogeochemistry of the coccolithophores with implications for coccolith-based isotopic proxies
}

\author{
Michaël Hermoso and Marceau Lecasble \\ Sorbonne Université, CNRS-INSU, Institut des Sciences de la Terre de Paris, 75005 Paris, France \\ Correspondence: Michaël Hermoso (michael.hermoso@ sorbonne-universite.fr)
}

Received: 24 July 2018 - Discussion started: 31 July 2018

Revised: 30 October 2018 - Accepted: 1 November 2018 - Published: 14 November 2018

\begin{abstract}
Reconstruction of sea surface temperatures from the oxygen isotope composition $\left(\delta^{18} \mathrm{O}\right)$ of calcite biominerals synthesised in the mesopelagic zone of the oceans requires knowledge of the $\delta^{18} \mathrm{O}$ of seawater and constraints on the magnitude of biological ${ }^{18} \mathrm{O} /{ }^{16} \mathrm{O}$ fractionation (the so-called vital effect). In the palaeoceanography community, seawater $\delta^{18} \mathrm{O}$ and salinity are unduly treated as a common parameter owing to their strong covariation both geographically and in the geological register. If the former parameter has arguably no notable influence on the biogeochemistry of marine calcifiers, salinity potentially does. However, how salinity per se and the effect of osmotic adjustment can modulate the biogeochemistry, and in turn, the expression of the vital effect in calcite biomineral such as the coccoliths remains undocumented. In this culture-based study of coccolithophores (Haptophyta) belonging to the Noelaerhabdaceae family, we kept temperature and seawater $\delta^{18} \mathrm{O}$ constant, and measured basic physiological parameters (growth rate and cell size), and the isotope composition $\left({ }^{18} \mathrm{O} /{ }^{16} \mathrm{O}\right.$ and $\left.{ }^{13} \mathrm{C} /{ }^{12} \mathrm{C}\right)$ of coccoliths grown under a range of salinity, between 29 and 39 . Ultimately, the overarching aim of this biogeochemical study is to refine the accuracy of palaeotemperature estimates using fossil coccoliths. We found that despite significant physiological changes in the coccolithophores, varying salinity does not modulate biological fractionation of oxygen isotopes. This observation contrasts with previous in vitro manipulations of temperature and carbonate chemistry that led to substantial changes in the expression of the vital effect. As such, salinity does not affect temperature estimation from coccolith-bearing pelagic sequences deposited during periods of change in ice volume, especially at the highest latitudes, or in coastal regions. By contrast, the carbon isotope composition of the coccoliths is influenced by a growth rate
\end{abstract}

mediated control of salinity with implications for deriving productivity indices from pelagic carbonate.

\section{Introduction}

Salinity of the surface of the open oceans exhibits a wide range of values, typically between 33 and 37, with more variability in coastal regions and in marginal seas (Antonov et al., 2010). Salinity has also changed significantly in the geological history, such as during the glacial and interglacial climate oscillations of the Plio-Pleistocene (Rostek et al., 1993; Schmidt et al., 2004; Thornalley et al., 2009) and during periods of emplacement of major ice-sheets in the Cenozoic (Zachos et al., 2001). Salinity is an important physicochemical factor that is of great influence on pelagic communities, and as such, on the biological pump and the carbon cycle (Sarmiento and Gruber, 2006). This parameter covaries with the oxygen isotope composition of seawater $\left(\delta^{18} \mathrm{O}_{\mathrm{sw}}\right)$, both latitudinally and geologically (LeGrande and Schmidt, 2006; Rohling and Bigg, 1998). This correlation is accounted for by a common control of the balance between evaporation and precipitation in a given area, and the volume of ice-caps at the highest latitudes. Therefore, salinity represents a signal of interest to constrain past environmental changes, but its variations are often approached as changes in $\delta^{18} \mathrm{O}_{\mathrm{sw}}$ values. Proxies for direct salinity reconstructions include the hydrogen isotope ratios $(\mathrm{D} / \mathrm{H})$ of alkenones or the $\mathrm{Na} / \mathrm{Ca}$ elemental ratios in foraminiferal calcite (Schouten et al., 2006; Wit et al., 2013). Moreover, despite possible large changes in salinity throughout an investigated time interval (e.g. glacialinterglacial cycles or longer-term studies), palaeoceanographers reconstructing sea surface temperatures (SSTs) from 
calcite $\delta^{18} \mathrm{O}$ ratios do not fully integrate the possible modulation of the vital effect induced by salinity changes per se.

Perturbation of the living environment of the coccolithophores (single-celled photosynthetic Haptophyta microalgae with the ability to biomineralise calcite intracellularly) has proven to significantly impact cellular growth rates and the geochemistry of the coccoliths in a wide range of isotopic and elementary systems (Bolton and Stoll, 2013; Candelier et al., 2013; Hermoso, 2015, 2016; Hermoso et al., 2015, 2016a, b, 2017; Holtz et al., 2015; Katz et al., 2017; McClelland et al., 2017; Rickaby et al., 2016; Stevenson et al., 2014; Tremblin et al., 2016). Thus, our working hypothesis is that salinity changes will impact the physiology of coccolithophore cells, and as such, the expression of the vital effects should be taken into account when applying isotopic proxies from coccolith-bearing sequences in the geological archive. To this aim, we cultured four strains of coccolithophore species in artificial media with salinities from 29 to 39 , and monitored cellular growth rates and cell sizes, and measured the isotopic composition $\left(\delta^{18} \mathrm{O}\right.$ and $\left.\delta^{13} \mathrm{C}\right)$ of the coccoliths.

\section{Materiel and methods}

\subsection{Preparation of the culture media}

We opted to conduct our cultures in artificial seawater, as diluting natural seawater would have led to covariations between salinity and $\delta{ }^{18} \mathrm{O}_{\mathrm{sw}}$. We thus maintained all ion ratios constant to better mimic natural environmental changes (Kirst, 1990). In total, we prepared two batches of $50 \mathrm{~L}$ each at salinity $S=39$ (hereafter, Sal39) by adding salts to de-ionised water following the ESAW recipe (Keller et al., 1987), and subsequently prepared the lower salinity batches with by re-diluting volumetrically the Sal39 batch with deionised water. We checked the salinity of each of the Sal29 to Sal39 batch by measuring the conductimetry of the media at room temperature. We used a TetraCon ${ }^{\circledR} 325$ conductimetry cell calibrated with $0.01 \mathrm{M} \mathrm{KCl}$ solution with a value of $1413 \mu \mathrm{S} \mathrm{cm}^{-1}$ at $25^{\circ} \mathrm{C}$. The correlation line linking conductimetry and salinity exhibited a root-square coefficient $\left(r^{2}\right)$ of 0.99 indicating the good yield and accuracy of the targeted salinities. Therefore, in the following account, we will express the salinities of our batches by the target values, as they depart from less than $0.5 \%$ with respect to the actual measurements.

The various media were subsequently amended in nitrate, phosphate, silica and trace metals, and vitamins as indicated in the $f / 2$ recipe to ensure that macro and micronutrient availability did not change with salinity. Medium $\mathrm{pH}$ was adjusted to 8.2 by addition of $1 \mathrm{~N} \mathrm{NaOH}$ solution. The last step of the preparation consisted of steri-filtration of the artificial medium using $0.22 \mu \mathrm{m}$ Millipore ${ }^{\circledR}$ Stericup ${ }^{\circledR}$ devices and the

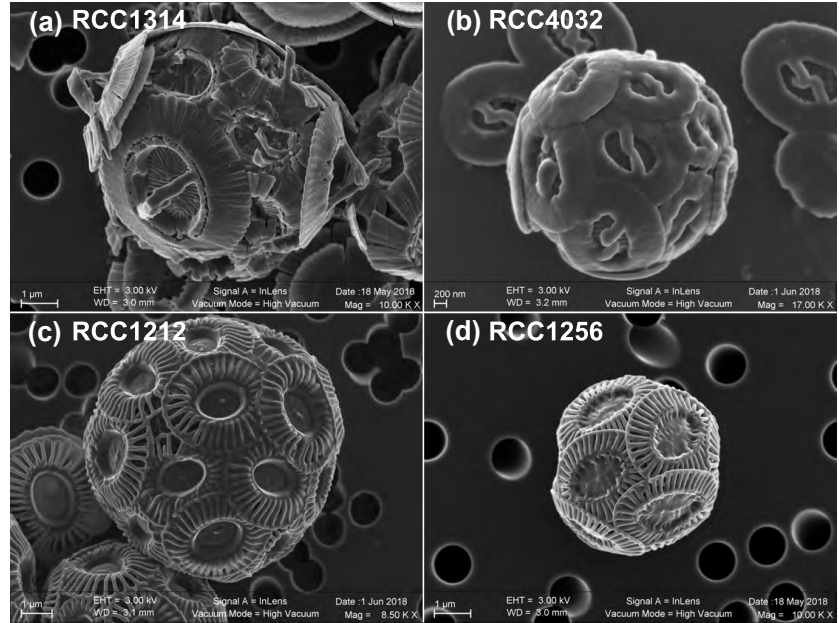

Figure 1. Scanning electron micrographs of the four strains of coccolithophores (Haptophyta) cultured in the present study. Key to strain ID: RCC1314 is Gephyrocapsa oceanica (a), RCC4032 is Gephyrocapsa ericsonii (b); RCC1212 is Emiliania huxleyi Morphotype B (c); and RCC1256 is Emiliania huxleyi Morphotype A (bottom right). Note the higher magnification for the smallest cells studied, namely RCC4032 (d).

transfer of the medium into sterile culture vessels for further algal inoculation.

\subsection{Strains selected and acclimatation phase}

We chose the following species and strains to conduct our experiments: Emiliania huxleyi morphotype A (strain RCC1256), Emiliania huxleyi morphotype B (strain RCC1212), Gephyrocapsa oceanica (strain RCC1314) and Gephyrocapsa ericsonii (strain RCC4032) (see Fig. 1 for SEM images of their coccospheres). The cultures were conducted at the biogeochemistry laboratory operating within the Institut des Sciences de la Terre de Paris. Firstly, the cells were transferred from natural seawater originating from the English Channel to our Sal35 batch and left for a month (i.e. more than 20 generations). We sub-cultured the algae every week in fresh medium. Subsequently, the four strains acclimated in ESAW medium at Sal35 were transferred in each salinity, and the acclimatation phase to the new salinity was made for another month with the same sub-culturing frequency. The transfer of RCC1314 G. oceanica and RCC4032 G. ericsonii into the two extreme conditions of Sal29 and Sal39, respectively, failed despite several attempts.

\subsection{Implementation of the batch cultures}

After the acclimation phase, the proper culture began with an initial concentration of cells around 200 cells $\mathrm{mL}^{-1}$ of medium in $150 \mathrm{~cm}^{2}$ polystyrene Thermo Scientific Nunc ${ }^{\circledR}$ culture flasks. Each strain/salinity experiment was conducted in duplicate. The medium was refreshed every 2 days fol- 
lowing a semi-continuous batch strategy (see Laroche et al., 2010). The cultures grew in a Panasonic ${ }^{\circledR}$ MLR 352 illuminated growth chamber. Temperature was kept constant at $15^{\circ} \mathrm{C}$, light irradiance was $\sim 150 \mu$ mol photons $\mathrm{m}^{-2} \mathrm{~s}^{-1}$ and the photoperiod lasted $14 \mathrm{~h}$ per day. These flasks were gently stirred twice a day, and prior to pipetting out $1 \mathrm{~mL}$ sterilely for cell numeration. Cell numeration was achieved using a Beckman ${ }^{\circledR}$ Coulter Counter ${ }^{\circledR}$ Multisizer IV fitted with a $70 \mu \mathrm{m}$ aperture tube. The measurements were made $3 \mathrm{~h}$ after the start of the illuminating period in the growth chamber. Calculation of the specific growth rates $(\mu)$ was made following Eq. (1):

$\mu=\frac{\ln (\text { cell conc } d)-\ln (\text { cell conc } d-n)}{n}$,

where $\mu$ is the specific growth rate, cell conc $d$ is the cell density in cells $\mathrm{mL}^{-1}$ at harvest, and cell conc $d-n$ is the cell density $n$ day before this measurement. $n$ is the number of days elapsed between these two measurements. The unit of $\mu$ is day ${ }^{-1}$.

The culture experiments were stopped when the densities reached 8000/10000 cells per mL. A final cell numeration was undertaken including the measurements of the size of the coccospheres (provided as a diameter-equivalent quantity by the Multisizer IV). The same aliquots were acidified by addition of $200 \mu \mathrm{L}$ of $0.2 \mathrm{M} \mathrm{HCl}$ in the cuvette, left for $5 \mathrm{~min}$ and the measurements were repeated to provide the diameter of the naked cells. Removal of the coccospheres that originally surrounded the cells were checked under an inverted microscope Zeiss Axio Vert.A $1^{\circledR}$ at 630 times magnification. Standardisation of size measurements on the Multisizer IV was done via a calibration procedure that used certified latex beads L10 with a $10.13 \mu$ m nominal diameter (batch 9747089F).

Harvest consisted in the suspensions containing the cells and free coccoliths to be poured onto polycarbonate membranes $(0.8 \mu \mathrm{m}$ nominal aperture $)$ and gathered by vacuumfiltration. The culture residues were rinsed with deionised water to prevent precipitation of salt during air-drying in a desiccating cabinet.

\subsection{Determination of isotopic ratios}

Aliquots of $0.22 \mu \mathrm{m}$ filtered water samples were analysed for their $\delta^{18} \mathrm{O}_{\mathrm{sw}}$ using a PICARRO CRDS (cavity ringdown spectrometer; model L2130-I Isotopic H2O) at the LOCEAN-IPSL lab in Paris. The $\delta^{13} \mathrm{C}$ of the dissolved inorganic carbon (DIC) was measured from $\mathrm{CO}_{2}(\mathrm{~g})$ released from water after injection of phosphoric acid $\left(\mathrm{H}_{3} \mathrm{PO}_{4} 85 \%\right)$, and determined using a dual inlet-isotopic ratio mass spectrometer (SIRA9-VG) in the same laboratory. These procedures and the standardisation are described in Racapé et al. (2010) and Benetti et al. (2017). The media were measured with $\delta^{18} \mathrm{O}_{\mathrm{sw}}=-6.55 \% \circ \pm 0.1 \%$ VSMOW, and $\delta^{13} \mathrm{C}$ of the DIC with values of $-12.40 \%$ $\pm 0.3 \%$ VPDB. The isotopic values were indistinguishable between batches of distinct salinities $(n=12)$.

For coccolith calcite, approximately $100 \mu \mathrm{g}$ of dry culture residue was weighted out and transferred into borosilicate vials. Calcite reacted with purified phosphoric acid at $70^{\circ} \mathrm{C}$ in a Kiel IV preparation device attached to a Thermo Scientific Delta V Advantage isotope ratio mass spectrometer at ISTeP, Sorbonne University. Stable isotope values were calibrated relative to the Vienna Pee Dee Belemnite (\%o VPDB) via the NBS-19 international standard. Reproducibility of measurements is $\pm 0.1 \%$ for the $\delta^{18} \mathrm{O}$ ratios and $\pm 0.05 \%$ o for the $\delta^{13} \mathrm{C}$ ratios.

\section{Results}

All the data generated for this study are available at https://doi.pangaea.de/10.1594/PANGAEA.895777 (Hermoso, 2018).

\subsection{Specific growth rates}

All strains exhibit significant changes in their specific growth rates in response to varying salinities (Fig. 2). Overall, the relationship between salinity and $\mu$ can be described by second-order polynomial curves (Supplement Table S1), with the exception of $G$. ericsonii, for which the measurements do not show a relation between $\mu$ and salinity (partly due to the Sal31 measurements). Gephyrocapsa oceanica, the largest cell studied here, grew faster at the lowest salinities Sal31 ( 0.52 day $\left.^{-1}\right)$, but did not grow at Sal29. The $\mu$ for this strain progressively decreased down to 0.17 day $^{-1}$ with increasing salinity. The relatively small cell of $G$. ericsonii shows the fastest division rate achieving more than one division per day for Sal33 and Sal35. The lowest salinities Sal29 and 31 exhibit $\mu$ values around 0.65 day $^{-1}$. They were significantly lower at the highest salinity Sal37, while no growth occurred at Sal39 for this strain.

The strain of Emiliania huxleyi producing coccoliths belonging to the Morphotype A (RCC1256) exhibits a bell curve for its salinity $/ \mu$ relationship $\left(r^{2}=0.91 ; p\right.$ value $<0.0005$ ) with a growth optimum at Sal33 (Fig. 2). On both sides of the maximum of ca. 0.7 day $^{-1}$ (for reference, representing a doubling population of cells every day on average), the growth rates are significantly lower, with a symmetrical response. Thus, growth rates are roughly halved at Sal29 and Sal39 compared to the optimum. The other strain of Emiliania huxleyi, RCC1212 Morphotype B, which is also much smaller in size, shows a different salinity $/ \mu$ relationship, as growth rates did not change significantly from around 0.7 day $^{-1}$ with our different salinity treatments, except for Sal29 that showed growth rates of only $\sim 0.3$ day $^{-1}$. 

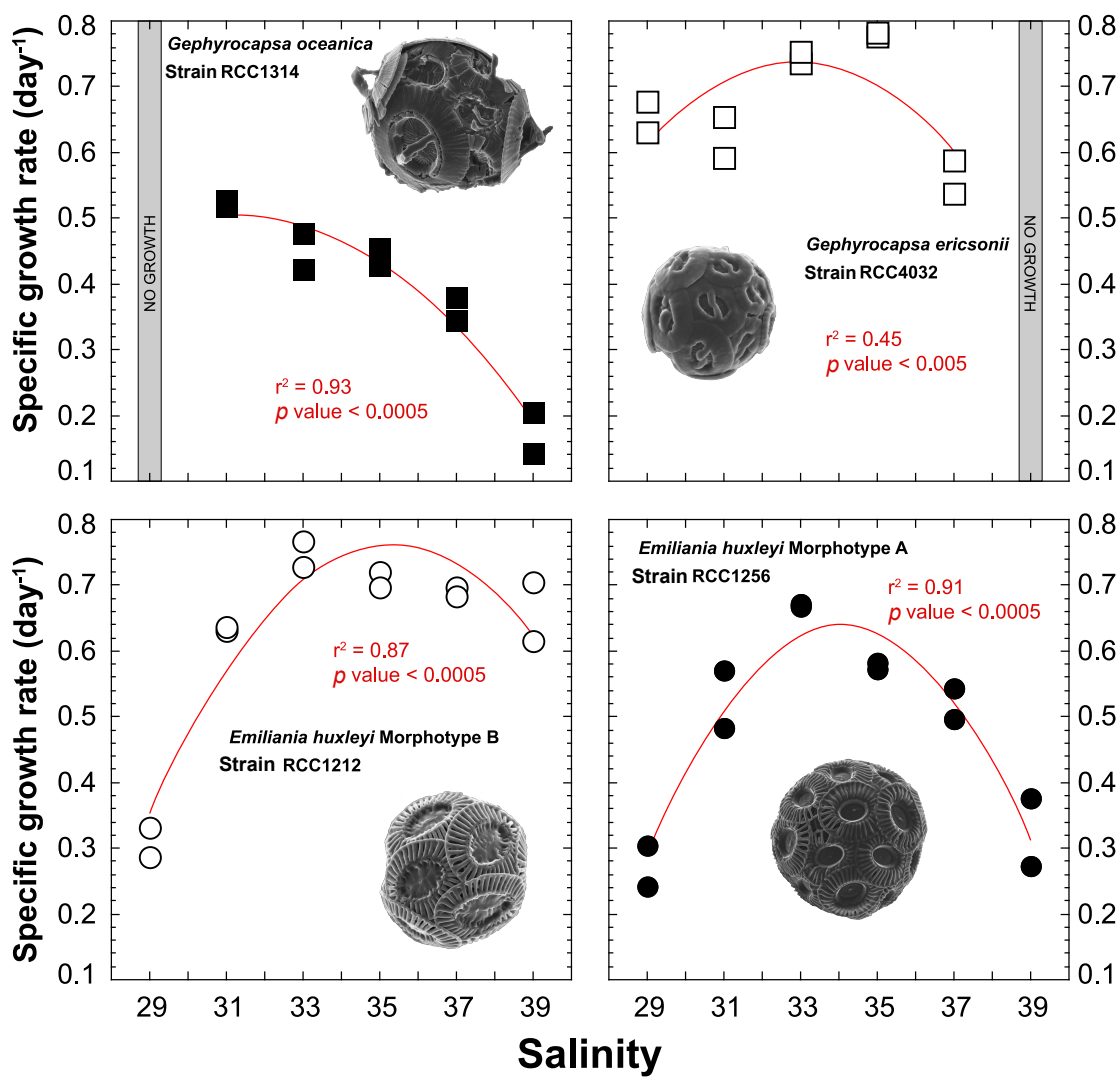

Figure 2. Effect of ambient salinity on the specific growth rates of coccolithophore algae. The data show a prominent modulation of growth rates, which appears to be strongly strain specific, with optimum growth achieved at salinities around 33, except for G. oceanica. All fits (red lines) correspond to a second-order polynomial law (not significant for RCC4032).

\subsection{Cell sizes (diameters)}

The strain RCC1314 of Gephyrocapsa oceanica exhibits an increase in cell diameter from $\sim 6$ to $\sim 7 \mu \mathrm{m}$ from Sal31 to Sal39 conditions (Fig. 3), which corresponds to an increase of the cellular volume by $60 \%\left(116\right.$ to $\left.188 \mu \mathrm{m}^{3}\right)$. This change can also be described by a second-order polynomial fit $\left(r^{2}=0.86 ; p\right.$ value $\left.<0.0005\right)$. The size of Gephyrocapsa ericsonii is also highly dependent on salinity $\left(r^{2}=0.95 ; p\right.$ value $<0.05$ ), with a progressive increase of the diameter and volume with increasing salinity, as observed for G. oceanica. We note, however, that the sizes for Sal35 and Sal37 are similar. For the small G. ericsonii cell, the relative variation in cell size is modest, less than $20 \%$ compared to its closerelative species G. oceanica.

Even though cell sizes of RCC1212 Emiliania huxleyi grown at different salinities range between 5 and $5.6 \mu \mathrm{m}(65$ and $95 \mu^{3}$ in volume), there is no clear trend in size or volume with ambient salinity (Fig. 3). The morphotype A of the same species shows a response in the cellular volume with salinity, as these two parameters are statistically linked by a polynomial fit $\left(r^{2}=0.81 ; p\right.$ value $\left.<0.0005\right)$ with a minimum value at the intermediate salinity (Sal31-27 $-47 \mu \mathrm{m}^{3}$ on average), whereas Sal29 and Sal39 are characterised by higher cell volumes $\left(87 \mu \mathrm{m}^{3}\right.$ for Sal29).

The volume of coccolithophore cells is an important physiological parameter reflecting the metabolic rates of the cells (Aloisi, 2015). Such a relationship (the higher the growth rate, the smaller the cell size) is expressed for G. oceanica (RCC1314) and the Morphotype A (RCC1256) of E. huxleyi $\left(r^{2}=0.82 ; p\right.$ value $<0.005$ and $0.62 ; p$ value $<0.005$, respectively) (Fig. 4), but is not for the two other strains, which do not exhibit responses describing a "bell curve" (second-order polynomial fit) with $\mathrm{p}$ values between 0.4 and 0.6 (Fig. 3).

\subsection{Isotopic ratios of coccolith calcite}

\subsubsection{Oxygen isotopes}

A practical means to express the isotopic results from calcite minerals in biogeochemistry and palaeoceanography is to use the " $\delta-\delta$ " notation, by which a pseudo-fractionation factor is expressed by the offset between $\delta^{18} \mathrm{O}_{\text {calcite }}$ and $\delta^{18} \mathrm{O}_{\text {sw }}$. Cultured coccoliths show a wide spread of $\delta^{18} \mathrm{O}_{\text {calcite }}-\delta^{18} \mathrm{O}_{\mathrm{sw}}$ 

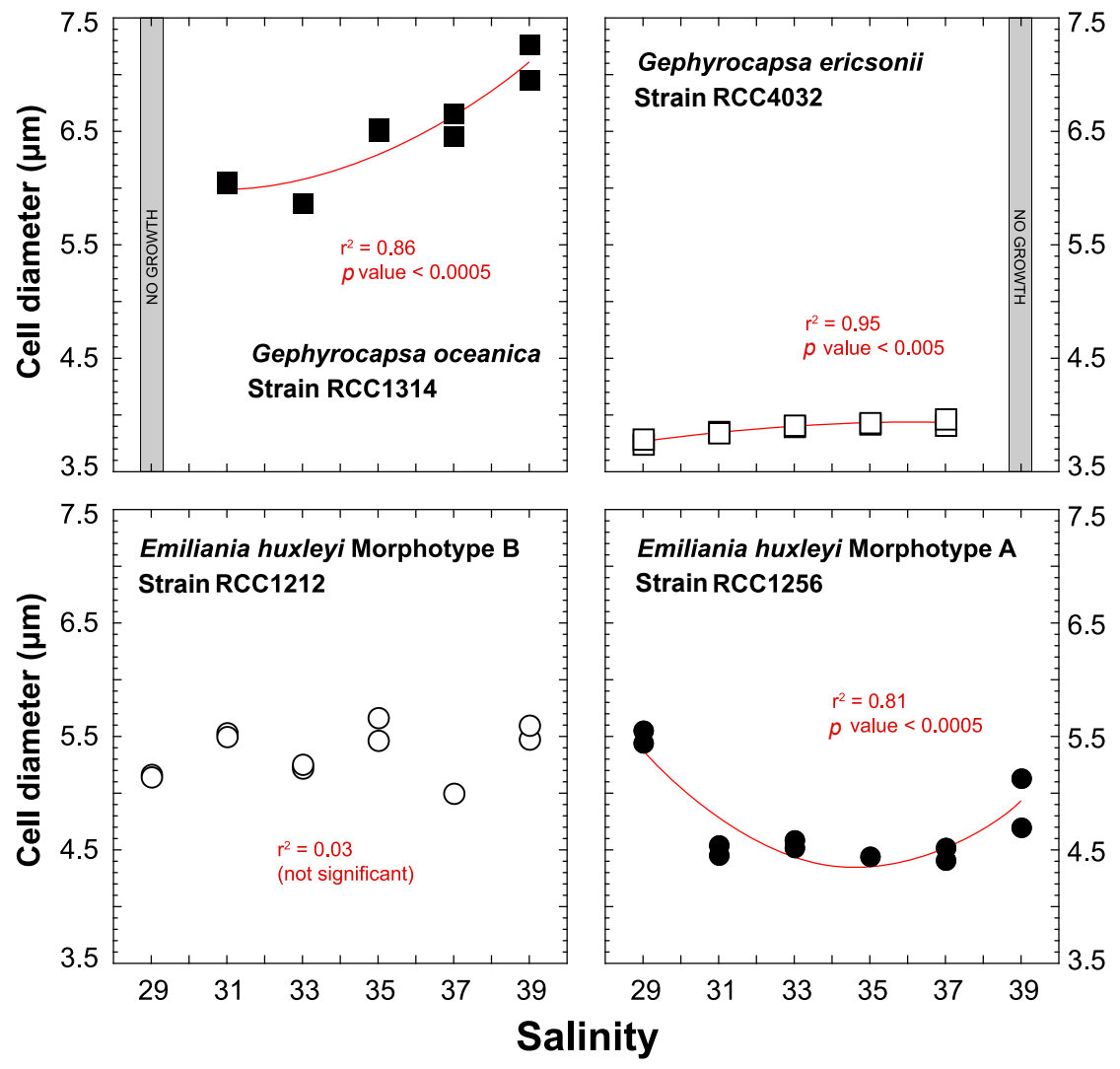

Figure 3. Effect of ambient salinity on the cell diameters of coccolithophore algae. As for growth rate, variations in the size of the cells (lightly decalcified coccospheres - see Methods) are species and strain dependent. All fits (red lines) correspond to a second-order polynomial law.

values between species, from $0.5 \%$ for G. oceanica to $2 \%$ o for $E$. huxleyi Morphotype A, but the variations for a given strain are much more limited, typically within a $\sim 0.35 \%$ o range (Fig. 5). Overall, there is no statistically significant relationship between salinity and the oxygen isotope composition of the coccoliths $\left(r^{2}<0.6 ; p\right.$ value around 0.01$)$. It seems that coccoliths produced by $G$. ericsonii exhibit increased $\delta^{18} \mathrm{O}$ values with increasing ambient salinity, but this correlation is not strong, given the reproducibility of the replicates with respect to the range of measured values on the Sal29-37 spectrum.

In our study, the $\delta^{18} \mathrm{O}_{\mathrm{sw}}$ did not significantly change with salinity, and temperature was kept constant at $15^{\circ} \mathrm{C}$, implying that changes in the isotopic composition of calcite correspond to a modulation of the expression of the vital effects by the coccolithophores. It is possible to compute the $\delta^{18} \mathrm{O}$ composition of an inorganic calcite following work by Kim and O'Neil (1997). This inorganic reference has been recently found to depart from equilibrium conditions (Watkins et al., 2013), but all previous literature on coccolith biogeochemistry, including the assignment of coccoliths into isotopically light and heavy groups (Dudley et al., 1986; Hermoso, 2014; Ziveri et al., 2003) are based on the Kim and O'Neil's study.
As our aim is to compare the isotopic composition of coccolith calcite grown by microalgae exposed to various salinities, without change in temperature and $\delta^{18} \mathrm{O}_{\mathrm{sw}}$, the use of this reference will not lead to an artefact for the biogeochemical signatures of the coccoliths. We calculated the oxygen isotope composition of such an inorganic calcite as $-6.59 \%$ o VPDB. The average magnitudes of the oxygen isotope vital effect are thus $+0.7 \%$ for RCC1314; $+1.6 \%$ for RCC 4032 ; $+1.6 \%$ for RCC1212; $+1.9 \%$ of $\mathrm{RCC} 1256$ - results that are in line with previously published coefficients of the vital effect, except for RCC4032 G. ericsonii for which no prior value exists. For RCC1314 Gephyrocapsa oceanica, the magnitude of the vital effect is slightly lower, by $0.5 \%$, than previous reports with cultures of the same strain grown in natural seawater (Hermoso et al., 2016a). This difference may be related to lower growth rates measured in our study at Sal 33-35 (0.45 day ${ }^{-1}$ in an artificial medium vs. 0.85 day $^{-1}$ in natural seawater). In all cases, the important feature of this dataset is that we found no influence of salinity on the oxygen isotope vital effects. 


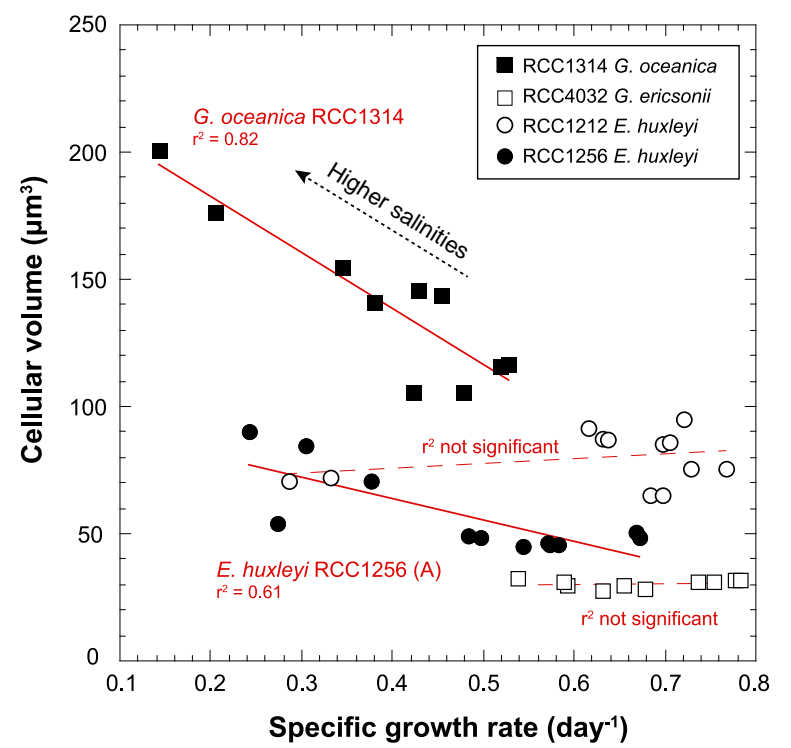

Figure 4. Covariations between growth rate and cell size of coccolithophores grown under various salinities. The conversion of the cell diameters into volumes have been achieved considering that the cells have are spherical. RCC1314 G. oceanica and RCC1256 E. huxleyi A show correlated changes in these two ecological-relevant parameters, however with distinct influence of salinity.

\subsubsection{Carbon isotopes}

The spread of $\delta^{13} \mathrm{C}_{\text {calcite }}-\delta^{13} \mathrm{C}_{\mathrm{DIC}}$ offsets for a given strain is within $1 \%$ o disregarding a non-replicated measurement for RCC1256 E. huxleyi at Sal37 (Fig. 6). Both Gephyrocapsa cells (RCC1314 and 4032) show comparable trends for the $\delta^{13} \mathrm{C}$ of their coccoliths with salinity, although the absolute values differ significantly (the former being $2 \%$ isotopically depleted compared to the latter). A negative trend is observed with increasing salinity, disregarding their lowest salinity data points. Such a trend is also evident for RCC1212 E. huxleyi, whereas for the other strain of E. huxleyi, there is not apparent link between $\delta^{13} \mathrm{C}$ values and salinity. Interestingly, the magnitude of these decreases in $\delta^{13} \mathrm{C}$ values seems to be common to all species, and can thus be quantified to $-1 \%$. For G. ericsonii, $\delta^{13} \mathrm{C}$ and $\mu$ are strongly correlated by a polynomial function $\left(r^{2}=0.91 ; p\right.$ value $\left.<0.05\right)$. This power fit is the mathematical consequence of the logarithmic expression of growth rate. Such a correlation is also seen, albeit statistically weaker, in RCC1212 E. huxleyi $\left(r^{2}=0.49\right)$, but not for the two other strains.

For the carbon isotopes, the composition of the inorganic calcite is given by Romanek et al. (1992) and is equal to $\delta^{13} \mathrm{C}_{\text {DIC }}+1$, hence $-11.40 \%$ VPDB in our case study. Thus, G. oceanica appears to be close $( \pm 0.5 \%$ ) to "equilibrium" conditions, whilst the other strains shift towards positive vital effects (up to $+3.3 \%$ o for RCC1212 E. huxleyi). These observations are also in good agreement with published literature
(Hermoso, 2015; Hermoso et al., 2014; Holtz et al., 2015; McClelland et al., 2017; Rickaby et al., 2010). There seems to be, in contrary to the oxygen isotope system, an influence of salinity on coccolith $\delta^{13} \mathrm{C}$ values, at least for three of the four strains being examined here.

\section{Discussion}

\subsection{The effect of salinity change on the physiology of the coccolithophores}

The seminal culture survey by Brand (1984) revealed the euryhaline nature of the coccolithophores Emiliania huxleyi and Gephyrocapsa oceanica, which have been successfully grown at salinities between 25 and 45, with some strains of E. huxleyi exhibiting limited growth under salinity as low as $15 \%$. Our data and other previous studies indicate that changing ambient salinity of the coccolithophores induces large changes in their growth rate (Fig. 7). In particular, it has been found that $E$. huxleyi and $G$. oceanica achieved better growth at the lowest salinities, with a lower limit of 25 for the former species (Fisher and Honjo, 1989; Saruwatari et al., 2016; Schouten et al., 2006). Except for Sal29, a salinity at which no growth was achieved by G. oceanica in our batches, our data for this species, and for G. ericsonii, are consistent with this overarching observation that the cells exhibit diminished growth rate with increasing salinity (Figs. 2 and 7). However, the salinity effect on growth rate for the two strains of E. huxleyi (RCC1212 and RCC1256) being examined here markedly differs from observations made by Fisher and Honjo (1989) and Schouten et al. (2006) (strains MHC1 \& G4 and PML B92/1, respectively), but are in line with those made on strain PLY B92/11 by Fielding et al. (2009). An optimum in division rates at salinity around 33 (the mean oceanic value and the salinity at which the strains have been maintained in culture for many years) is evident in our data for E. huxleyi Morphotypes A and B. The reason(s) behind this discrepancy are not straightforward to discuss beyond methodology, and may pertain to physiological differences and distinct adaptabilities to changing environment of the multiple ecotypes of E. huxleyi (e.g. Rickaby et al., 2016).

Our experiments only deal with short-term adaptability of the coccolithophores exposed to relatively abrupt changes in salinity, necessitating rapid adaptation to the osmotic stress imposed on the cells in our treatments. The physiological implications regarding turgor stressor are complex, involving osmotic adjustment and the understanding of the precise mechanisms at play is beyond the scope of this paper. These aspects are not described in any great detail in the existing literature. We see contrasting responses in cellular sizes forced by ambient salinity among the strains grown in this study. Gephyrocapsa oceanica and G. ericsonii exhibit relatively smaller cell sizes at the lowest salinity (Fig. 4), while the opposite response is observed for the Morphotype A of E. hux- 


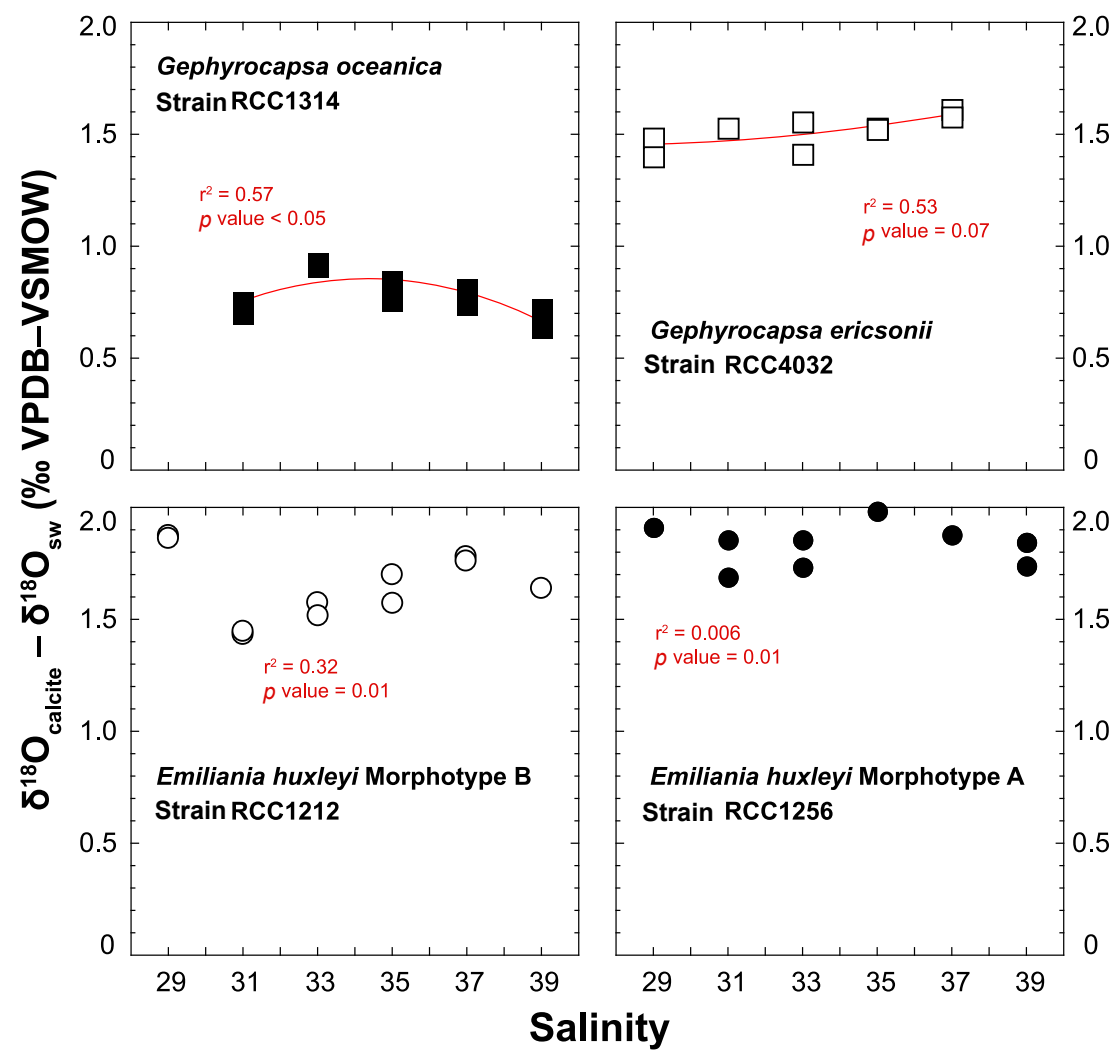

Figure 5. Effect of ambient salinity on the oxygen isotope composition of coccolith calcite. The variations in the isotopic composition of the coccolith are relatively minor, less than $0.35 \%$ o for a considered strain with our salinity treatments. The spread of isotopic data is slightly larger for RCC1212 E. huxleyi $(0.5 \%$ o), but there is no salinity dependence on growth rates observed for this strain. For reference, the Kim and O'Neil's calcite composition is around $0 \%$ VPDB. At $15^{\circ} \mathrm{C}$, the vital effect can thus be quantified by the $\delta^{18} \mathrm{O}_{\text {calcite }}-\delta^{18} \mathrm{O}_{\text {sw }}$ offset. These positive values indicate that all the investigated species belong to the "isotopic heavy group". All fits (red lines) correspond to a second-order polynomial law (see Table S1).

leyi. Meanwhile, there seems to be no response for the Morphotype B of E. huxleyi. The presence of active transporters (or membrane pumps) may vary in type, number and effective rates between various coccolithophore species. As a consequence, these possibly distinct strain-specific features will affect the transport and diffusion of water across the membrane, thus influencing the size of the cell and leading to the observed differences between $G$. oceanica, G. ericsonii, and the two strains of E. huxleyi.

The preparation of our culture media did not only change the ionic concentrations of the dominant $\mathrm{Na}^{+}$and $\mathrm{Cl}^{-}$ions, but also induced coeval compositional changes in elements relevant to photosynthetic and calcifying unicellular organisms. Indeed, from the Sal39 down to Sal29 conditions, $\left[\mathrm{Ca}^{2+}\right]$ and [DIC] decreased in the same ratio as salinity. Thus, a secondary effect from simultaneous changes in $\mathrm{Ca}^{2+}$ and DIC concentrations is therefore possible. For the lowest salinities, diluted $\mathrm{Ca}^{2+}$ and DIC may become limiting for coccolithophore growth and intracellular calcification (calcium has also a role in cell signalling), superimposing a re- sponse to salinity per se. If the concentration and availability of DIC substantially decreased with decreasing salinity (constant 39:29 ratio), the availability of aqueous $\mathrm{CO}_{2}$ in equilibrium with the lab air first and with the headspace in the culture flask during the batch culture remained relatively unchanged. It is well established that coccolithophore algae predominantly source the carbon resource from their external environment in the form of aqueous $\mathrm{CO}_{2 \mathrm{aq}}$ (McClelland et al., 2017). Thus, the ambient concentration in $\mathrm{CO}_{2}$ is the primary parameter dictating cellular growth with implications for the expression of the isotopic vital effects (Bolton and Stoll, 2013; Hermoso, 2014). We calculated the variations in $\left[\mathrm{CO}_{2 \mathrm{aq}}\right]$ using $\mathrm{CO} 2 \mathrm{CALC}$ software (Robbins et al., 2010) and found indeed only relatively modest changes (on the order of $1 \%$ ) from Sal39 to Sal29. Salinity has little effect on the $\mathrm{CO}_{2 \text { air }} / \mathrm{CO}_{2 \mathrm{aq}}$ equilibrium according to Henry's law, conversely with temperature. Furthermore, the linear changes in the concentrations of DIC, $\mathrm{CO}_{2 \mathrm{aq}}$ and calcium on the entire salinity spectrum are not compatible with the bell curves observed in the measurements of coccolithophore physiol- 


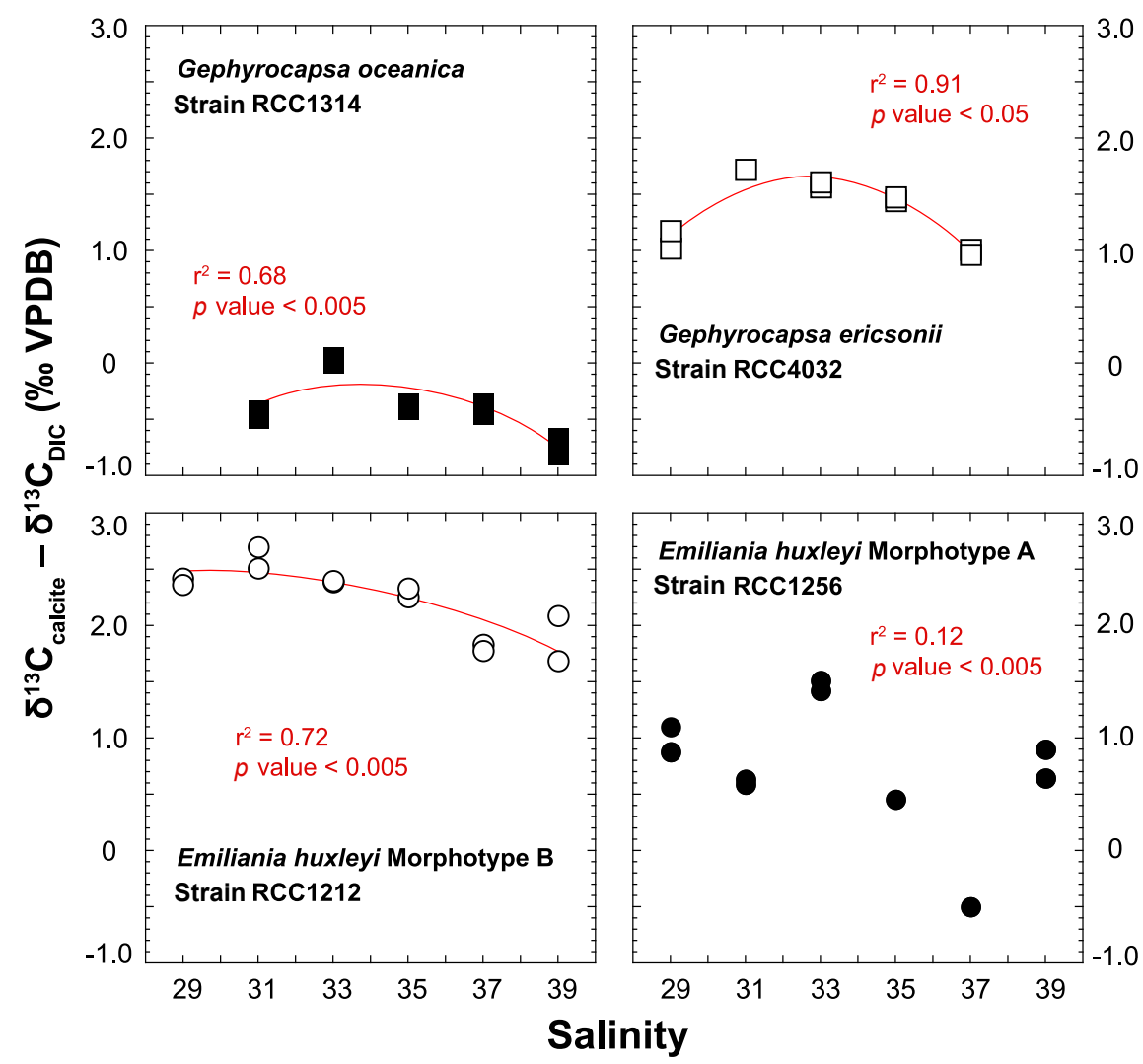

Figure 6. Effect of ambient salinity on the carbon isotope composition of coccolith calcite. There is an influence of salinity, or a parameter itself influenced by salinity (growth rate) on the stable carbon isotope composition of the coccoliths. The is a general decrease in $\delta^{13} \mathrm{C}$ values with salinity, particularly well expressed on the Sal33-39 spectrum. RCC1256 E. huxleyi shows an appreciable spread in the data without a clear correlation between salinity and $\delta^{13} \mathrm{C}$ values.

ogy that exhibit optima around Sal33-35. This question was also dealt with in work by Paasche et al. (1996) who conducted calcium and bicarbonate enrichment in low salinity waters, and found no alleviation of depressed growth rates. It is therefore unlikely that lowered growth rates at salinities lower than the optimum values are caused by decreases in the carbon and calcium resources. Therefore, we can confirm that the modulations of growth observed in our study are salinity-induced changes. Which ionic species (such as $\mathrm{Na}^{+}$, $\mathrm{Cl}^{-}, \mathrm{SO}_{4}^{2-}$ ) exerts the dominant control of salinity on the coccolithophores at the cellular level remains an open question.

\subsection{The effect of salinity change on the isotopic composition of coccolith biominerals}

\subsubsection{Current knowledge of biological fractionation in coccolithophore calcite}

Coccolithophores source DIC from the external environment to sustain growth (photosynthesis) and intracellular mineralisation (calcification). The proportion of $\mathrm{CO}_{2 \text { aq }}$ and
$\mathrm{HCO}_{3}^{-}$assimilated by the cells primarily depends on ambient $\left[\mathrm{CO}_{2 \mathrm{aq}}\right]$ and the inducible expression of active mechanisms to uptake carbon in the form of $\mathrm{CO}_{2 \mathrm{aq}}$ (excretion of carbonic anhydrase in the periplasmic environment) and $\mathrm{HCO}_{3}^{-}$(transmembrane transporters). Within the cells, the residence of the DIC pool between assimilation and biomineralisation of DIC in the coccolith vesicle, and the relative allocation of the carbon resource into photosynthesis relative to calcification have large implications on the isotopic composition of coccolith calcite, both for the oxygen and carbon systems (Bolton and Stoll, 2013; Hermoso, 2014; Hermoso et al., 2016a, b; Holtz et al., 2015; McClelland et al., 2017; Rickaby et al., 2010).

Specific to relatively small and fast growing species within the Noelaerhabdaceae family (the taxa to which our four strains belong), the coccoliths measured in our study have high $\delta^{18} \mathrm{O}$ and $\delta^{13} \mathrm{C}$ ratios compared to other species (see review in Hermoso, 2014). These isotopic values are higher than inorganic conditions, and as such have been attributed to the isotopic "heavy group" (Dudley et al., 1986). Although transported by the same molecules and eventually measured from the same mineral, oxygen and carbon atoms have dis- 


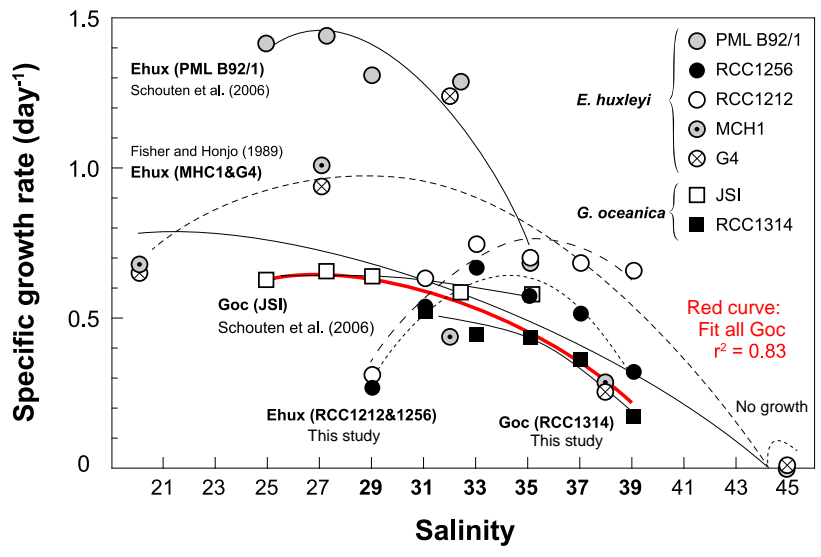

Figure 7. Compilation of previously published data documenting the variations of the specific growth rates of coccolithophores with salinity, and data of the present study shown on Fig. 2. The source for previous studies is inset. It is apparent that growth rates diminish with increasing salinity with a large variability in the response according to the considered strain, especially for E. huxleyi. By contrast, data for G. oceanica seem to be in good agreement between studies and strains (red curve), disregarding the fact that no growth was achieved by RCC1314 at Sal29 in our study. Overall, this graph highlights the euryhaline nature of open ocean microalgae that typifies the ecology of the coccolithophores thriving in the oceans and maintained in the laboratory under salinities nearing 33 .

tinct behaviours in terms of dynamic of the two isotopic systems, and the controlling factor dictating equilibrium condition to which is superimposed biological fractionation. These main differences include a large reservoir of atoms for the oxygen (DIC \& ambient water molecules that constantly exchange ${ }^{18} \mathrm{O}$ and ${ }^{16} \mathrm{O}$ ); a sluggish re-equilibration time once a disequilibrium is created; and the temperature-dependence of fractionation between ${ }^{18} \mathrm{O}$ and ${ }^{16} \mathrm{O}$ between calcite and water (Zeebe and Wolf-Gladrow, 2001). For the carbon system, the size of the pool is markedly smaller than for the oxygen. Photosynthesis favours ${ }^{12} \mathrm{C}$ at the expense of ${ }^{13} \mathrm{C}$ atoms, leaving the internal pool isotopically more positive with implications for the carbon pool that will be allocated to calcification. The extent to which calcite $\delta^{13} \mathrm{C}$ will be pushed towards more positive values obeys to Rayleigh distillation driven by photosynthetic ${ }^{12} \mathrm{C}$ fixation, and the relative allocation of DIC into photosynthesis and calcification (referred to as the PIC:POC ratio; particulate inorganic carbon relative to particulate organic carbon). With these biogeochemical processes in mind, isotopic heavy $\delta^{18} \mathrm{O}$ values for Gephyrocapsa and Emiliania coccoliths arise from fast growth and the biomineralisation of the predominantly sourced $\mathrm{CO}_{2 \mathrm{aq}}$ by the cells that occurs prior to full equilibration between ${ }^{18} \mathrm{O}$ excess-bearing-DIC and $\mathrm{H}_{2} \mathrm{O}$ (Hermoso et al., 2014, 2016a). Relatively high $\delta^{13} \mathrm{C}$ of Gephyrocapsa and Emiliania calcite can be explained by the small size of these cells, and, overall, by low PIC:POC ratios, as POC exceed PIC in these fast growing species (more can be read in McClelland et al., 2017).

\subsubsection{Implications for the temperature proxy based on $\delta^{18} \mathrm{O}$ composition}

The $\delta^{18} \mathrm{O}$ signature of calcite remains the most widely used quantitative temperature proxy in palaeoceanography. Assuming that constraints on the magnitude of the vital effect can be established and also assuming constant $\delta^{18} \mathrm{O}_{\mathrm{sw}}$, a decrease by $1 \%$ corresponds to an increase in temperature by $4{ }^{\circ} \mathrm{C}$ following thermodynamic predictions (Watkins et al., 2013). There are many factors, however, that can obscure the reliability of this $\delta^{18} \mathrm{O}$-temperature relationship, such as the environmentally driven change in the magnitude of biological fractionation.

Previous culture studies have highlighted large modulation of the expression of the vital effect under manipulation of the growth environment without changing the isotopic composition of the DIC or $\delta^{18} \mathrm{O}_{\mathrm{sw}}$ with implications for the temperature proxy. In particular, the concentrations of ambient $\mathrm{CO}_{2 \mathrm{aq}}$ have proven to represent a major driver of the vital effect: The more availability of carbon around the cell, the less the vital effect (Hermoso et al., 2016b). Changing salinity induced comparable changes in cellular growth rate comparable in magnitudes to those induced by manipulation of temperature and carbonate chemistry ([DIC] \& $\mathrm{pH}$ ) in previous culture studies of the coccolithophores. Yet, the vital effects are relatively stable for a given strain with temperature and $\delta^{18} \mathrm{O}_{\text {sw }}$ being kept constant in our experiments (Fig. 5). When translated into temperature estimates, the most conservative error (averaging replicated measurements) from our $\delta^{18} \mathrm{O}_{\text {coccoliths }}$ is $0.4^{\circ} \mathrm{C}$. As discussed in the previous section, coeval changes in the concentrations of $\mathrm{CO}_{2 \mathrm{aq}}$ remain very limited. This important finding pertaining the biogeochemistry of the coccolithophores indicates that marked changes in seawater salinity through geological history, e.g. during glacial and interglacial changes at high latitudes or during the emplacement of large continental ice-sheets, would have no impact on the reliability of the $\delta^{18} \mathrm{O}$-temperature proxy in fossil coccoliths, at least for those belonging the Noelaerhabdaceae family. More research will be needed in the future to test whether our conclusion could be extended to other geologically relevant taxa.

\subsubsection{Implications for the palaeoproductivity proxy based on $\delta^{13} \mathrm{C}$ composition}

The significance of $\delta^{13} \mathrm{C}$ ratios of pelagic carbonates is not as clear as the $\delta^{18} \mathrm{O}$ proxy in the palaeoceanographic toolbox. The $\delta^{13} \mathrm{C}$ tool depends on the timescale being considered with changes in $\delta^{13} \mathrm{C}$ composition of seawater and carbonate being potentially due to rapid shifts in ocean circulation, upwelling, or changes in primary productivity. As organic carbon has negative carbon isotope ratios relative to DIC, 
periods of increasing productivity and organic carbon export to the seafloor are characterised by increased carbonate $\delta^{13} \mathrm{C}$, noting that this control resembles processes operating at the intracellular level and dictating coccolith $\delta^{13} \mathrm{C}$ values described above. An emerging research avenue utilises the differential expression of carbon limitation by large vs. small coccolithophore cells as the new proxy for $p \mathrm{CO}_{2}$ (Tremblin et al., 2016).

We see covariations between salinity, growth rates, and in turn, $\delta^{13} \mathrm{C}$ values of the coccoliths cultured in our study, especially for the smaller cells. For G. ericsonii, $\delta^{13} \mathrm{C}$ and $\mu$ are strongly correlated $\left(r^{2}=0.91 ; p\right.$ value $\left.<0.0005\right)$. The $\Delta \delta^{13} \mathrm{C}$ variations of $1 \%$ on the range of investigated salinity are important considering the natural variations of this isotopic tracer in geological past. We note that the $\delta^{13} \mathrm{C}$ of DIC did not change among batches of distinct salinity. As a result, the progressive decrease in coccolith $\delta^{13} \mathrm{C}$ with increasing salinity can be the consequence of changing growth rates, but also could originate from the fact that less carbon is allocated to photosynthesis relative to calcification (meaning at first order that at the lower salinities, calcification is hampered). In the absence of measurements of PIC:POC ratios in our study (due to too low mass of residue harvested), it remains difficult to discuss these isotopic changes from a mechanistic point of view at the intracellular level. We hope that the detailed salinity $/{ }^{13} \mathrm{C}$ relationship will be scrutinised in the future, in particular to extend our understanding of the carbon isotope vital effects beyond $p \mathrm{CO}_{2}$ and temperature.

\section{Conclusion and future work}

Open ocean microalgae, as coccolithophore microalgae, are confirmed to be euryhaline organisms able to thrive under salinities from 29 to 39 . Their tolerance to salinity changes and the induced modulation of their growth rates appear to be strain-specific, with an overall growth optimum around 33, the salinity of their natural environment. The physiological mechanisms and, in particular, those involved in the osmotic regulation of the coccolithophore cells grown under such a wide range of salinity are not well constrained, and more work is clearly needed from the biological side to achieve such an understanding.

From a geological proxy perspective, we showed here that substantial, and rapid - for timescales compatible with adaptation - changes in ambient salinity have no impact on oxygen isotope fractionation by coccolithophores. As such, coccolith $\delta^{18} \mathrm{O}$-derived sea surface temperature estimates are not compromised by this parameter that has been shown to significantly affect algal growth. Future culture studies will have to determine whether this observation can be extended to other geologically relevant species, such as those belonging to the Coccolithaceae or Calcidiscacea families. Likewise, it would be extremely valuable to investigate the potential of $\mathrm{Na} / \mathrm{Ca}$ ratios in coccolith calcite as proxy for ancient salinity (as done in foraminifera) and to conduct morphometric analyses of these minute biominerals with the same objective (see recent methods by Hermoso and Minoletti (2018)).

Data availability. All the data generated for this studied are available at https://doi.pangaea.de/10.1594/PANGAEA.895777 (Hermoso, 2018).

Supplement. The supplement related to this article is available online at: https://doi.org/10.5194/bg-15-6761-2018-supplement.

Author contributions. $\mathrm{MH}$ designed the experiments. ML and $\mathrm{MH}$ conducted the experiments. MH wrote the manuscript with inputs from ML.

Competing interests. The authors declare that they have no conflict of interest.

Acknowledgements. The data presented in the present study are from the Master's research project of Marceau Lecasble under the supervision of Michaël Hermoso in 2018. We thank Nathalie Labourdette, Aïcha Namar, and Gilles Reverdin for measurements of the isotopic ratios of carbonates and waters. Ian Probert is warmly thanked for providing the strains grown in this study. We are grateful to Fabrice Minoletti for continuous support and to François Baudin for making possible the use of the Multisizer IV apparatus. We acknowledge with thanks the inputs of the associate editor Markus Kienast, Lennart de Nooijer and one anonymous reviewer. Michaël Hermoso acknowledges financial support from the French Agence Nationale de la Recherche (ANR) - Project "CARCLIM" under reference ANR-17-CE01-0004-01 and from the Cluster of Excellence "MATISSE" led by Sorbonne Université under reference ANR-11-IDEX-0004-02. Part of this work was also supported by the Mission pour l'Interdisciplinarité of the French Centre National de la Recherche Scientifique (CNRS) in the framework of the Défi ISOTOP with a grant awarded to Fabrice Minoletti and Michaël Hermoso - Project "COCCOTOP”. The setting-up of the culture facilities in Paris was made possible thanks to all of these funding bodies and to the host research unit (ISTeP) via a Coup de Pouce Action.

Edited by: Markus Kienast

Reviewed by: Lennart de Nooijer and one anonymous referee

\section{References}

Aloisi, G.: Covariation of metabolic rates and cell size in coccolithophores, Biogeosciences, 12, 4665-4692, https://doi.org/10.5194/bg-12-4665-2015, 2015.

Antonov, J. I., Seidov, D., Boyer, T. P., Locarnini, R. ., Mishonov, A. V., Garcia, H. E., Baranova, O. K., Zweng, M. M., and Johnson, 
D. R.: World Ocean Atlas 2009 (Volume 2: Salinity), U.S. Gov., edited by: Levitus, S., Washinton D.C., 2010.

Benetti, M., Reverdin, G., Aloisi, G., and Sveinbjörnsdóttir, Á.: Stable isotopes in surface waters of the Atlantic Ocean: Indicators of ocean-atmosphere water fluxes and oceanic mixing processes, J. Geophys. Res.-Oceans, 122, 4723-4742, https://doi.org/10.1002/2017JC012712, 2017.

Bolton, C. T. and Stoll, H. M.: Late Miocene threshold response of marine algae to carbon dioxide limitation, Nature, 500, 558-562, https://doi.org/10.1038/nature12448, 2013.

Brand, L. E.: The salinity tolerance of forty-six marine phytoplankton isolates, Estuar. Coast. Shelf S., 18, 543-556, https://doi.org/10.1016/0272-7714(84)90089-1, 1984.

Candelier, Y., Minoletti, F., Probert, I., and Hermoso, M.: Temperature dependence of oxygen isotope fractionation in coccolith calcite: A culture and core top calibration of the genus Calcidiscus, Geochim. Cosmochim. Ac., 100, 264-281, https://doi.org/10.1016/j.gca.2012.09.040, 2013.

Dudley, W., Blackwelder, P., Brand, L., and Duplessy, J.-C.: Stable isotopic composition of coccoliths, Mar. Micropaleontol., 10, 18, 1986.

Fielding, S. R., Herrle, J. O., Bollmann, J., Worden, R. H., and Montagnes, D. J. S.: Assessing the applicability of Emiliania huxleyi coccolith morphology as a seasurface salinity proxy, Limnol. Oceanogr., 54, 1475-1480, https://doi.org/10.4319/lo.2009.54.5.1475, 2009.

Fisher, N. S. and Honjo, S.: Intraspecific Differences in Temperature and Salinity Responses in the Coccolithophore Emiliania huxleyi, Biol. Oceanogr., 6, 355-361, 1989.

Hermoso, M.: Coccolith-derived isotopic proxies in palaeoceanography: Where geologists need biologists, Cryptogamie Algol., 35, 323-351, https://doi.org/10.7872/crya.v35.iss4.2014.323, 2014.

Hermoso, M.: Control of ambient $\mathrm{pH}$ on growth and stable isotopes in phytoplanktonic calcifying algae, Paleoceanography, 30, PA002844, https://doi.org/10.1002/2015PA002844, 2015.

Hermoso, M.: Isotopic record of Pleistocene glacial/interglacial cycles in pelagic carbonates: Revisiting historical data from the Caribbean Sea, Quaternary Sci. Rev., 137, 69-78, https://doi.org/10.1016/j.quascirev.2016.02.003, 2016.

Hermoso, M.: Changes in growth parameters of cultured coccolithophores and isotopic composition of coccolith calcite with salinity, PANGAEA, https://doi.pangaea.de/10.1594/ PANGAEA.895777, 2018.

Hermoso, M. and Minoletti, F.: Mass and Fine-Scale Morphological Changes Induced by Changing Seawater $\mathrm{pH}$ in the Coccolith Gephyrocapsa oceanica, J. Geophys. Res.-Biogeo., 123, 27612774, https://doi.org/10.1029/2018JG004535, 2018.

Hermoso, M., Horner, T. J., Minoletti, F., and Rickaby, R. E. M.: Constraints on the vital effect in coccolithophore and dinoflagellate calcite by oxygen isotopic modification of seawater, Geochim. Cosmochim. Ac., 44, 612-627, https://doi.org/10.1016/j.gca.2014.05.002, 2014.

Hermoso, M., Candelier, Y., Browning, T. J. T. J., and Minoletti, F.: Environmental control of the isotopic composition of subfossil coccolith calcite: Are laboratory culture data transferable to the natural environment?, GeoResJ, 7, 35-42, https://doi.org/10.1016/j.grj.2015.05.002, 2015.
Hermoso, M., Minoletti, F., Aloisi, G., Bonifacie, M., McClelland, H. L. O., Labourdette, N., Renforth, P., Chaduteau, C., and Rickaby, R. E. M.: An explanation for the ${ }^{18} \mathrm{O}$ excess in Noelaerhabdaceae coccolith calcite, Geochim. Cosmochim. Ac., 189, 132 142, https://doi.org/10.1016/j.gca.2016.06.016, 2016a.

Hermoso, M., Chan, I. Z. X., McClelland, H. L. O., Heureux, A. M. C., and Rickaby, R. E. M.: Vanishing coccolith vital effects with alleviated carbon limitation, Biogeosciences, 13, 301-312, https://doi.org/10.5194/bg-13-301-2016, 2016 b.

Hermoso, M., Lefeuvre, B., Minoletti, F., and de Rafélis, M.: Extreme strontium concentrations reveal specific biomineralization pathways in certain coccolithophores with implications for the $\mathrm{Sr} / \mathrm{Ca}$ paleoproductivity proxy, PLoS One, 12, e0185655, https://doi.org/10.1371/journal.pone.0185655, 2017.

Holtz, L.-M., Wolf-Gladrow, D., and Thoms, S.: Numerical cell model investigating cellular carbon fluxes in Emiliania huxleyi, J. Theor. Biol., 364, 305-315, https://doi.org/10.1016/j.jtbi.2014.08.040, 2015.

Katz, A., Bonifacie, M., Hermoso, M., Cartigny, P., and Calmels, D.: Laboratory-grown coccoliths exhibit no vital effect in clumped isotope $\left(\Delta_{47}\right)$ composition on a range of geologically relevant temperatures, Geochim. Cosmochim. Ac., 208, 335353, https://doi.org/10.1016/j.gca.2017.02.025, 2017.

Keller, M. D., Selvin, R. C., Claus, W., and Guillard, R. R. L.: Media for the culture of oceanic ultraphytoplankton, J. Phycol., 23, 633-638, https://doi.org/10.1111/j.15298817.1987.tb04217.x, 1987.

Kim, S.-T. and O'Neil, J. R.: Equilibrium and nonequilibrium oxygen isotope effects in synthetic carbonates, Geochim. Cosmochim. Ac., 61, 3461-3475, https://doi.org/10.1016/S00167037(97)00169-5, 1997.

Kirst, G. O.: Salinity Tolerance of Eukaryotic Marine Algae, Annu. Rev. Plant Phys., 41, 21-53, https://doi.org/10.1146/annurev.pp.41.060190.000321, 1990.

Laroche, J., Rost, B., and Engel, A.: Guide to best practices for ocean acidification research and data reporting, in: Part 2: Experimental design of perturbation experiments Bioassays, batch culture and chemostat experimentation, edited by: Riebesell, U., Fabry, V. J., Hansson, L., and Gattuso, J.-P., Publications Office of the European, Luxembourg, 81-94, 2010.

LeGrande, A. N. and Schmidt, G. A.: Global gridded data set of the oxygen isotopic composition in seawater, Geophys. Res. Lett., 33, L12604, https://doi.org/10.1029/2006GL026011, 2006.

McClelland, H. L. O., Bruggeman, J., Hermoso, M., and Rickaby, R. E. M.: The origin of carbon isotope vital effects in coccolith calcite, Nat. Commun., 8, 14511, https://doi.org/10.1038/ncomms14511, 2017.

Paasche, E., Brubak, S., Skattebøl, S., Young, J. R., and Green, J. C.: Growth and calcification in the coccolithophorid Emiliania huxleyi (Haptophyceae) at low salinities, Phycologia, 35, 394 403, https://doi.org/10.2216/i0031-8884-35-5-394.1, 1996.

Racapé, V., Monaco, L., Metzl, N., and Pierre, C.: Summer and winter distribution of $\delta^{13} \mathrm{CDIC}$ in surface waters of the South Indian Ocean $\left[20^{\circ} \mathrm{S}-60^{\circ} \mathrm{S}\right]$, Tellus B, 62, 660-673, https://doi.org/10.1111/j.1600-0889.2010.00504.x, 2010.

Rickaby, R. E. M., Henderiks, J., and Young, J. N.: Perturbing phytoplankton: response and isotopic fractionation with changing carbonate chemistry in two coccolithophore species, Clim. Past, 6, 771-785, https://doi.org/10.5194/cp-6-771-2010, 2010. 
Rickaby, R. E. M., Hermoso, M., Lee, R. B. Y., Rae, B. D., Heureux, A. M. C., Balestreri, C., Chakravarti, L., Schroeder, D. C., and Brownlee, C.: Environmental carbonate chemistry selects for phenotype of recently isolated strains of Emiliania huxleyi, Deep-Sea Res. Pt. II, 127, 28-40, https://doi.org/10.1016/j.dsr2.2016.02.010, 2016.

Robbins, L. L., Hansen, M. E., Kleypas, J. A., and Meylan, S. C.: $\mathrm{CO}_{2}$ calc - A user-friendly seawater carbon calculator for Windows, Max OS X, and iOS (iPhone), U.S. Geol. Surv. - File Rep., 1280, 2010.

Rohling, E. J. and Bigg, G. R.: Paleosalinity and $\delta^{18} \mathrm{O}$ : A critical assessment, J. Geophys. Res.-Oceans, 103, 1307-1318, https://doi.org/10.1029/97JC01047, 1998.

Romanek, C. S., Morse, J. W., and Grossman, E. L.: Carbon isotopic fractionation in synthetic aragonite and calcite: Effects of temperature and precipitation rate, Geochim. Cosmochim. Ac., 56, 419-430, 1992.

Rostek, F., Ruhlandt, G., Bassinot, F. C., Muller, P. J., Labeyrie, L. D., Lancelot, Y., and Bard, E.: Reconstructing sea surface temperature and salinity using $\delta^{18} \mathrm{O}$ andalkenone records, Nature, 364, 319-321, https://doi.org/10.1038/364319a0, 1993.

Sarmiento, J. and Gruber, N.: Ocean Biogeochemical Dynamics, Princeton., edited by: Sarmiento, J. and Gruber, N., Princeton University Press, Oxford, 2006.

Saruwatari, K., Satoh, M., Harada, N., Suzuki, I., and Shiraiwa, Y.: Change in coccolith size and morphology due to response to temperature and salinity in coccolithophore Emiliania huxleyi (Haptophyta) isolated from the Bering and Chukchi seas, Biogeosciences, 13, 2743-2755, https://doi.org/10.5194/bg-132743-2016, 2016.

Schmidt, M. W., Spero, H. J., and Lea, D. W.: Links between salinity variation in the Caribbean and North Atlantic thermohaline circulation, Nature, 428, 160-163, https://doi.org/10.1038/nature02346, 2004.

Schouten, S., Ossebaar, J., Schreiber, K., Kienhuis, M. V. M., Langer, G., Benthien, A., and Bijma, J.: The effect of temperature, salinity and growth rate on the stable hydrogen isotopic composition of long chain alkenones produced by Emiliania huxleyi and Gephyrocapsa oceanica, Biogeosciences, 3, 113-119, https://doi.org/10.5194/bg-3-113-2006, 2006.
Stevenson, E. I., Hermoso, M., Rickaby, R. E. M., Tyler, J. J., Minoletti, F., Parkinson, I. J., Mokadem, F., and Burton, K. W.: Controls on Stable strontium isotope fractionation in coccolithophores with implications for the marine $\mathrm{Sr}$ cycle, Geochim. Cosmochim. Ac., 128, 225-235, https://doi.org/10.1016/j.gca.2013.11.043, 2014.

Thornalley, D. J. R., Elderfield, H., and McCave, I. N.: Holocene oscillations in temperature and salinity of the surface subpolar North Atlantic, Nature, 457, 711-714, https://doi.org/10.1038/nature07717, 2009.

Tremblin, M., Hermoso, M., and Minoletti, F.: Equatorial heat accumulation as a long-term trigger of permanent Antarctic icesheets during the Cenozoic, P. Natl. Acad. Sci. USA, 113, 11782 11787, https://doi.org/10.1073/pnas.1608100113, 2016.

Watkins, J. M., Nielsen, L. C., Ryerson, F. J., and DePaolo, D. J.: The influence of kinetics on the oxygen isotope composition of calcium carbonate, Earth Planet. Sc. Lett., 375, 349-360, https://doi.org/10.1016/j.epsl.2013.05.054, 2013.

Wit, J. C., de Nooijer, L. J., Wolthers, M., and Reichart, G. J.: A novel salinity proxy based on $\mathrm{Na}$ incorporation into foraminiferal calcite, Biogeosciences, 10, 6375-6387, https://doi.org/10.5194/bg-10-6375-2013, 2013.

Zachos, J., Pagani, M., Sloan, L., Thomas, E., and Billups, K.: Trends, rhythms, and aberrations in global climate $65 \mathrm{Ma}$ to present., Science, 292, 686-693, https://doi.org/10.1126/science.1059412, 2001.

Zeebe, R. E. and Wolf-Gladrow: $\mathrm{CO}_{2}$ in Seawater: Equilibrium, Kinetics, Isotopes, Elsevier, 2001.

Ziveri, P., Stoll, H., Probert, I., Klaas, C., Geisen, M., Ganssen, G., and Young, J.: Stable isotope "vital effects" in coccolith calcite, Earth Planet. Sc. Lett., 210, 137-149, https://doi.org/10.1016/S0012-821X(03)00101-8, 2003. 